\title{
Does Class Action Have a Deterrent Effect?
}

\author{
Comment \\ by \\ Christoph Engel*
}

Data are the oil that fuels the empirical legal movement. The paper by Klement and Weinshall-Margel (2016) comes with a full barrel of this oil. The paper is based on a complete data set of all class action suits that have ever been filed since Israel introduced class action in 2006. The data were hand-coded by third- and fourth-year law students under the supervision of trained lawyers, and come with a rich set of potential explanatory variables. Just describing the data provides legal academia with valuable insights. To list only two: the new procedural tool is almost exclusively used for consumer complaints and complaints against government; the attorney and the representative plaintiff on average even make money if the case is dismissed.

In this note I try to push the analysis one step further and use the data for finding causal evidence on a claim that has been prominent in the political debate on class action. In a landmark ruling, Judge Posner dismissed the decision of a district court to grant class action certification for a hemophiliac who had contracted AIDS from a contaminated blood transfusion. The main argument was: class action certification gives plaintiff excessive leverage for obtaining a "blackmail settlement" (In re Rhone-Poulenc Rorer Inc., U.S. Court of Appeals 7th Circuit, No. 94-3912, decided March 16, 1995). This argument presupposes that the availability of class action increases the probability that the case will ultimately go to court; otherwise the threat would be empty. But is this a sound assumption? If true, countries that allow for class action would make it more difficult for a would-be tortfeasor to get away with violating an entire class.

For showing whether class action indeed deters socially undesirable behavior, one would need data from a control group where sufficiently comparable behavior is possible, but class action is not available. To make sure that a potential deterrent effect is indeed caused by class action, the difference between the two groups should ideally be random. Such data are not available for Israel. But as I hope to show in the following pages, the existing data are rich enough to test whether, at least, class action has the deterrent effect that was at the core of Judge Posner's argument: when the risk of class action is real, a conflict is more likely to go to court.

\footnotetext{
* Max Planck Institute for the Research on Collective Goods, Bonn, Germany.
} 
I am most grateful to Alon Klement and Keren Weinshall-Margel for sharing their data with me to put this claim to the test.

The identification of causal effects requires random variation. I work with the identifying assumption that the size of the class and the size of the claim for the representative plaintiff are exogenous. Both depend on the substance of the conflict and can arguably not be manipulated by the parties. This variation is helpful in that the product of the two indicators is a measure for the economic value of the case. The value of the case may serve as a proxy for the risk that a case will be tried if it is positively correlated with the attorney's and the representative plaintiff's expected profit. This is not obvious, since the courts have discretion in defining both profits (for detail see Klement and Weinshall-Margel, 2016). Yet empirically this correlation is indeed observed (Table 1).

Table 1

Manipulation Check

\begin{tabular}{lcccc}
\hline & Model 1 & Model 2 & Model 3 & Model 4 \\
\hline Dependent variable & \multicolumn{2}{c}{ Attorney fee } & Payment to class representative \\
Case value & $0.0000512^{* * *}$ & & $0.0000108^{* * *}$ & \\
& $(0.00000493)$ & & $(0.00000056)$ & \\
$\ln$ (case value) & & $15845.46^{*}$ & & $4557.74^{* *}$ \\
& & $(6326.308)$ & & $(1577.925)$ \\
Cons & $64890.88^{* * *}$ & $-187092.30^{+}$ & $19867.45^{* * *}$ & $-53174.36^{*}$ \\
& $(9584.883)$ & $(99187.57)$ & $(3153.087)$ & $(23899.70)$ \\
$n$ & 258 & 258 & 256 & 256 \\
$p$ model & $<0.0001$ & 0.0129 & $<0.0001$ & 0.0042 \\
\hline
\end{tabular}

Notes: OLS; case value: \# of members of the class $\times$ size of the individual claim; ${ }^{* * *} p<$ $0.001,{ }^{* *} p<0.01,{ }^{*} p<0.05,{ }^{+} p<0.1$.

Ex ante the outcome of a court case is hardly ever certain. Legal doctrine is ambiguous, and the facts are frequently disputed. It is difficult to predict beforehand whether plaintiff will be able to prove her case to the requisite standard. On the other hand, plaintiffs are not clueless about the odds of winning. If the availability of class action exerts a deterrent effect, where class action is available more marginal cases should go to court. In this hypothesis, marginal means that the odds of winning are less favorable for plaintiff. This is where I can exploit the exogenous variation in case value. It implies that marginal cases are the more likely to go to court the higher the case value. If true, plaintiff should be the more likely to lose a class action suit the higher the case value. This prediction follows from the fact that attorneys and representative plaintiffs have the more to gain from bringing a class action suit the 
higher the value of the case. In expectation, the risk of bringing a less obvious case is worth taking.

As Klement and Weinshall-Margel (2016) explain, actual court rulings are rare in class action. Yet the fact that the case is settled, rather than dropped, is a good proxy for success. For the typical defendant would rather settle a case that looks promising than accept the additional cost and risk involved in trying the case. There are two technical challenges for the estimation, though. One does not find a significant effect when explaining settlement with the actual case value. As the figure shows, this variable suffers from an obvious outlier problem. This is why I work with the log transform; it is almost perfectly normally distributed. As Klement and Weinshall-Margel (2016) explain, the composition of case types is very uneven. Different judges have also dealt with very differently many class action suits. Both observations call for fixed effects. Yet cases brought before several judges, and some infrequent case types for that matter, have never settled. Were I to estimate with logit the effect of case value on the probability that the case settles, I would lose those data points, since these fixed effects perfectly predict failure. This is why I estimate linear probability models.

\section{Figure}

Distribution of Case Values

Original Data

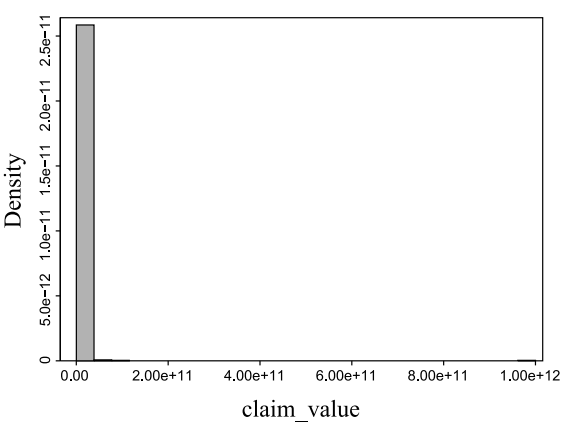

Logged

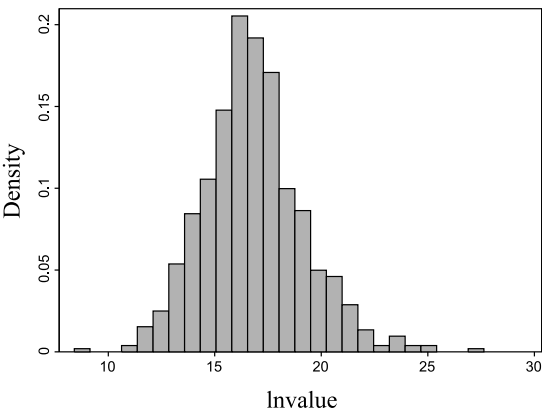

The regressions in Table 2 show that, indeed, the arguably exogenous case value has a negative effect on the probability that the case settles. Without controls, the effect is still insignificant (model 1). But the picture progressively clears with adding judge fixed effects (model 2), adding case-type fixed effects (model 3), and controlling for the time trend (model 4). The latter is important because, as Klement and Weinshall-Margel (2016) show, the number of class action suits has been increasing rapidly over time.

This comment has been deliberately complementary to the very useful main paper. It tries to show that, even when convincing data on control groups are not available, 
Table 2

Effect of Case Value on Success Probability

\begin{tabular}{lcccc}
\hline & Model 1 & Model 2 & Model 3 & Model 4 \\
\hline $\ln$ (case value) & -0.005 & $-0.013^{*}$ & $-0.016^{* *}$ & $-0.019^{* *}$ \\
& $(0.005)$ & $(0.006)$ & $(0.006)$ & $(0.006)$ \\
Judge fixed effects & & yes & yes & yes \\
Case-type fixed effects & & & yes & yes \\
Date & & & $-0.0001921^{* * *}$ \\
& & & & $(0.0000481)$ \\
Cons & $0.250^{* *}$ & $0.190^{*}$ & $0.245^{* *}$ & $0.546^{* * *}$ \\
& $(0.084)$ & $(0.086)$ & $(0.086)$ & $(0.115)$ \\
$n$ & 705 & 688 & 687 & 687 \\
\hline
\end{tabular}

Notes: OLS (linear probability model); dependent variable: dummy that is 1 if the case is settled; date: day when case was filed, expressed as day count that starts with earliest case in data set; ${ }^{* *} p<0.001,{ }^{* *} p<0.01,{ }^{*} p<0.05,{ }^{+} p<0.1$.

this comprehensive data set of all class action suits that have ever been brought in Israel lends itself to causal analysis, and to additional contributions to the scholarly and to the policy debate. Most likely, many more applications are still to be made with these data.

\section{References}

Klement, A., and K. Weinshall-Margel (2016), "Cost-Benefit Analysis of Class Action: An Israeli Perspective," Journal of Institutional and Theoretical Economics (JITE), 172(1), $75-103$.

Christoph Engel

Max Planck Institute

for Research on Collective Goods

Kurt-Schumacher-Str. 10

53121 Bonn

Germany

engel@ coll.mpg.de 